\title{
THE KNOWLEDGE - AS PRODUCTION FACTOR
}

\author{
Enachi Mihaela, Teaching assistant, UNIVERSITY OF BACAU
}

\begin{abstract}
:
In the current economic context, knowledge becomes the new nucleus of progress. If in the traditional economy the production factors were land, labor and capital, in the new economy knowledge is the major component of the productive system. Through the present study we try to clarify the position of knowledge in the production system and its role as a production factor, by explaining how it effective acts and contributes to the increase of welfare at the organizational and national levels.
\end{abstract}

\section{Keywords:}

knowledge, residual production factor, individual production factor, economic growth.

We will try, first, to clarify the position of knowledge in the production process, assessing the role played by it, namely, the quality of residual production factor or individual production factor.

The knowledge has been part of the production process since the beginning of human species. Thus, obtaining food in primitive era couldn't be made without knowing if fruits, vegetables etc. are edible and not toxic, then for hunting our ancestors had to know what weapons to use, how many people must action for success, what is easier to catch etc. The knowledge was needed after both the evolution of agrarian civilization and industrialism and the more in the Third Wave, that of knowledge. Without learning and knowledge the human species would not survive, would not have occurred achievement or expand of production, and thus economic growth.

Paying today again attention to the knowledge, recognizing its contribution to the production process, we only relocated it where always begin. Key role of the knowledge is shown also through the fact that, while under the traditional theory of economic growth, each marginal unit of resource (labor, land, capital), added over a certain level, produces increasingly less effects, in the case of knowledge these marginal rate is not decreasing but increasing.

First, we detail some of the issues leading to the idea that knowledge could be considered a residual production factor, being found in some of the traditional production factors, in different weights.

Economists who considered that when we speak about knowledge we are dealing with a residual production factor, very important in the productive system, presented some opinions according to which knowledge is reflected by the quality of work and the design of capital goods. They therefore argue that we find knowledge as part of two of the traditional factors, labor and capital.

In this regard, Alfred Marshall sees knowledge as a part of the capital, Adam Smith considers the division of labor as the fundamental cause of the knowledge accumulation (we inferred from these the inclusion of knowledge in labor), and Fritz Machlup considers the technology as a form of knowledge and white-collar workers the only knowledge producers, and he treats the knowledge as a factor whose value is 
almost impossible to determine separately, as it present a variety of structural elements, coming from multiple areas.

Thus, Machlup identifies five types of knowledge (practical, intellectual, from smalltalk and pastime, spiritual, ,unwanted” or accidentally acquired), both scientific and common, which can be obtained by formal or informal way (as sources of learning he identifies: family, school, trainings on the job, church, armed forces, television, selfeducation, experience), through various means.

As justification for considering knowledge as a residual factor, we can mention the impossibility of creating capital without the support of knowledge and the impossibility of adequately conducting the business by the human factor in the absence of absolute needed knowledge in various stages of production. It is therefore very difficult to separate the two traditional production factors from knowledge factor, the more there are involved here a variety of tacit knowledge and knowledge acquired and used as the production process is carried out.

Moreover, should not overlook the fact that, perhaps more quickly than other inputs, as time passes and changes in the economy accelerate, knowledge becomes obsolete and practically devoid of utility and hence value. Although some knowledge of the past come sometimes back to life proving useful due to changes in the context they are assigned, receiving such a new meaning, often the opposite is true.

We will continue by presenting some of the reasons for which knowledge is considered an individual production factor. In this respect, we will use a definition that present knowledge as the sum of our perceptions and understandings about nature and society (which may not be correct), while learning is the process by which individuals or organizations acquire new knowledge (here knowledge novelty is rather relative than absolute).

Thus, an economic theory of knowledge at the state level could be called ,national learning capability", considered the capability to assimilate new knowledge and to use it to improve the welfare. This is a system determined by three dimensions: infrastructure for learning (existing knowledge base and resources for formal and informal learning), institution (foundation of a society's formal environmental in which individuals make calculations about their possibilities of action and make decisions on the type of initiative that should be taken for their material or nonmaterial gains within their own capacities and social limits) and culture (social context that shapes individuals preferences over institutions and efforts to explore opportunities under a given social environment).

National learning capability is a subsystem within the production system, the three factors of its, above-mentioned, two-way interacting with the three traditional production factors (labor, land and capital).

Some of those interactions, listed for exemplification, are referring to the following issues: the population size determines the possible resource learning oriented, and the learning contributes to population growth by reducing mortality rate, which is possible by increasing the supply channels, providing healthier nutritional options, more effective fight the diseases etc.; the small in size and population or underdeveloped territories tend to feel more vulnerable, which could increase the attractiveness for learning, and the learning can lead to an increased power in master nature, people being able to find solutions for replacing scarce natural resources through more efficient use of them, finding alternative, and sometimes discovering new resources; the capital influences learning capacity by providing necessary resources for this process take place, being known that the rate of technological progress depends of capital used in research and development, while the learning affects capital accumulation through its contribution to the production process, since capital is the result of production. 
The knowledge presents many features of other production factors, but also many differences. For example, it may in certain circumstances (with the support of label), replace the land by providing solutions for the creation of artificial resources, can, like capital, be acquired, replace labor, but unlike capital which can be completely separated from work, some of it (especially the tacit one) can not work alone because it can not easily be converted into tangible forms.

Peter Drucker points out that absolutely decisive production factor is neither capital, nor labor, nor land, basic economic resource is and will continue to be the knowledge. In fact, knowledge is the only significant resource today, but the traditional production factors didn't disappear, but became secondary.

Alvin Toffler believes that while the labor, land and capital were the main factors of production of the Second Wave, the knowledge is the basic resource for the economy of the Third Wave. This intangible asset have become a key resource, which gradually replace the traditional ones, offering the possibility of reducing other inputs used in increasing wealth.

Considering knowledge a distinct resource, the production function elaborated on the basis of four variables can be presented as: $\mathrm{X}=\mathrm{F}(\mathrm{Q}, \mathrm{N}, \mathrm{K}, \mathrm{L})$. In this function $\mathrm{Q}$ is due to the sum of scientific, technological and social knowledge, $\mathrm{N}$ is the land or nature, $\mathrm{K}$ is capital and $\mathrm{L}$ refers to labor.

Robert Solow, like other economists, present the residual factor or total factor productivity (TFP), respectively the quantity of output unexplained by the inputs used in production, like a result generated primarily by scientific and technological progress. Of course it is accepted that single, scientific and technological knowledge, are not sufficient to lead to economic growth, the social ones being also essential. By integrating both scientific and technological knowledge and social ones in the production function we can better explain the causes of economic growth, leaving less room to accidental events.

Although the share of knowledge, regardless of how it is integrated into the production function, is very low, around $1 \%$, its contribution to economic growth is estimated to rise to $90 \%$.

We can speak of four types of knowledge important in the new economy:

- know-what (to know what): refers to knowledge of different facts, phenomena, processes; this is the most widespread and less usable as such in the production process, but represent the basis for other kinds of knowledge;

- know-why (to know why): refers to knowledge about the causation of different facts, processes, phenomena, respectively the scientific knowledge on the principles and laws of nature, on it relying technological development and renewal of products and services; often it is the result of basic scientific research;

- know-how (to know how): refers to the skills and abilities to do something, the knowledge relating to practical experience, contributing substantially to the production and commercialization of products and services; the basis for this, most often, is represented by research type application;

- know-who (to know who): refers to those who know what and those who know how to do that something, involving the formation of special social relationships that provide access to experts and on the efficient use of their knowledge.

If „to know what” and „to know why” may be found by consulting various materials, "to know how" and „to know who" are rooted primarily in practical experience. More important for the growth of welfare are often the last two types of knowledge mentioned.

For taking notice of several differences between traditional production factors and knowledge factor, I presented in what follows the general characteristics of the knowledge which, in summary, are considering the following aspects of that: 
- is non-rival: the same knowledge can be used by any number of people without reducing the existing amount (in addition, the more it is used by more many people, the more possibility there is to generate more knowledge from existing one; knowledge is by its nature inexhaustible);

- is non-exclusive: it is not possible to exclude someone who wishes to use it, respectively the amount of knowledge used by one person does not diminish the amount that other people can use;

- is relational: any individual piece of that makes sense only when juxtaposed with other pieces which provide the context (sometimes this context can be communicated nonverbal or paraverbal);

- is collegial: the more numerous is, the more complex, numerous and varied possible useful combinations are;

- is easier to carry than any of the resources: it can be transmitted instantly to one or more persons, wherever they are located, at the same infinitesimal price;

- can be stored in pieces increasingly smaller and using a variety of means (memory of individuals, different material or electronic means);

- can be compressed in symbols and abstractions;

- is intangible: we can not touch it, but we can manipulate it;

- is non-linear: small ideas can bring amazing results;

- is heterogeneous: not have a homogeneous content, and the places where it is produced are varied;

- is difficult to isolate, it is spreading;

- may be explicit or implicit, expressed or not, shared or tacit.

These characteristics being known is very difficult to achieve the measurement of knowledge contribution to economic growth, it affecting not only the resulted quantity, but also the way in which the products and services are obtained. However, some specialists have proposed some series of indicators that could be used to measure knowledge, few such views being given in what follows.

If Robert Solow presented the utility of the production function in determining the contribution of knowledge to economic growth through the link established between the quantity of inputs and outputs of the production process, Fritz Machlup believes that knowledge can not be measured starting from the production function because these is only an abstract construction involved in the characterization of some quantitative relations considered relevant in terms of empirical, without allowing the information about the causality of those relations.

Thus, to measure knowledge Machlup use national accounts, although knowledge was not represented and isn't representing a category of National System of Accounts. He uses, in this regard, two indicators: „knowledge industries” and „knowledge workers”. The first of those refers to organizations, departments or teams within them and, sometimes, individuals and families who produce knowledge for their own use or for the use of others. The second indicator takes into account workers who have functions in production and dissemination of knowledge.

According to the OECD report The Knowledge-based Economy, from 1996, also in measuring knowledge can be used indicators such as: the research and development expenditure, the engineers and technical personnel employment degree, the patents, the licenses, the know-how, the international balance of payments for technology etc. Other indicators that can be used to measure knowledge, beginning from the learning behind its accumulation, are: the rate of literacy, the number of high-school or college graduates, the number of people involved in research and development, the freedom of action, the degree of social responsibility etc.

Despite of all attempts to propose different ways to measure the contribution of knowledge to economic growth, it remains a part of it, although very important in the 
production process, impossible to evaluate because of its tacit existence and from that of the impossibility of being codified in any conditions of manifestation.

Although the evaluation of knowledge remains not fully solved because of the characteristics it has, however, paying particular attention to it by treating as a critical input to the growth of welfare is important. It is expected that in the future the productivity of knowledge will make the difference between the rich and less rich countries, running accessing, using and producing knowledge activities being crucial to organizational and national economic success.

\section{References:}

[1] Machlup. F., The Production and Distribution of Knowledge in the United States, Princeton University Press, USA, 1973

[2] Năstase, C., Economia cunoaşterii. Note de curs, Universitatea „Ştefan cel Mare” Suceava, Facultatea de Ştiinţe Economice şi Administraţie Publică, Suceava, 2009

[3] Popescu, R., Tehnologie şi inovare în economia cunoaşterii, Editura Chiminform Data, Bucureşti, 2007

[4] Suciu, M.C., Economia cunoaşterii şi civilizaţia globală: investiţia şi speranţa în om, Editura ASE, Bucureşti, 2002

[5] Toffler, A., Heidi, A., Revolutionary Wealth, Knopf, USA, 2006, tradusă în limba română de către Năstase, A., Năstase, N., sub titlul Avuţia în mişcare, Editura Antet XX Press, Prahova, 2006

[6] OECD, The Knowledge-based Economy, Paris, 1996, disponibil la adresa http://www.oecd.org/dataoecd/51/8/1913021.pdf

[7] Andone, I., Valoarea cunoaşterii în societatea bazată pe competiţie, în Revista Informatica Economică, nr. 1(25), pp.7-13, INFOREC Association, Bucureşti, 2003

[8] Dinu, M., Socol, C., From Solow Model to Endogenous Economic Growth - Romania's Reinsertion into Civilization?, în Revista Informatica Economică, nr. 1 (37), pp. 122-127, INFOREC Association, Bucureşti, 2006

[9] Godin, B., The Knowledge Economy: Fritz's Machlup's Construction of a Synthetic Concept, Project on the History and Sociology of S\&T Statistics, Working Paper nr. 37, 2008, disponibil la adresa www.csiic.ca/PDF/Godin_37.pdf

[10] Luban, F., Breazu, G., Managementul cunoştinţelor, în Revista Economia, nr. 1-2, pp. 5356, Editura ASE, Bucureşti, 2000

[11] Machlup. F., The Supply of Inventors and Invention, in the National Bureau of Economic Research, Volume The Rate and Direction of Inventive Activity: Economic and Social Factors, pp. 143-169, UMI, 1962, disponibil la adresa http://www.nber.org/chapters/c2116.pdf?new_window $=1$

[12] Solow, R.M., Technical Change and the Aggregate Production Function, in The Review of Economics and Statistics, Vol. 39, No. 3, pp. 312-320, Mass Inst of Technology Press, USA, 1957

[13] Tang, Sh., Knowledge as Production Factor: Toward a Unified Theory of Economics Growth, 2005, disponibil la adresa http://iaps.cass.cn/English/Articles/showcontent.asp?id $=406$

[14] Witt, U, Brokel, T, Brenner, Th., Knowledge and its Economic Characteristics - A Conceptual Clarification, in the Jena Economic Research Papers 2007-013, FriedrichSchiller-University Jena, Germany, 2007

$[15] \quad * * *$ http://www.scribd.com/doc/6719626/Intrarea-In-Era-Economiei-Bazata-PeCunoastere. 